\title{
THE SERVICE ENCOUNTER IN HIGHER EDUCATION INSTITUTIONS: A SYSTEMATIC LITERATURE REVIEW
}

\author{
Steven Kayambazinthu Msosa'
}

\begin{abstract}
This paper reviews existing literature on the service encounter in higher education institutions. It aims to analyse and provide more insight on the term service encounter, identify dimensions, the types of service encounter and how the service encounter is evaluated. The service encounter (SE) is a critical aspect of the service delivery process. It is used to determine whether the service delivered has been satisfactory or dissatisfactory. Furthermore, the service encounter offers an opportunity for the service provider to demonstrate his or her ability to offer a remarkable experience. However, it has been proven that many service providers do not take advantage of the service encounter to create student satisfaction. As a result, many encounters have left marks of unpleasant and negative feelings on the student. In higher education institutions, the service encounter helps both students and academicians communicate and understand the needs of either party. This study adopted a systematic review of the literature using several academic databases. A plethora of studies on the service encounter were reviewed from several academic databases but only 50 articles published from 1984 to 2018 were cited in this study. A descriptive analysis was used to highlight the classification of the sources used, the number of articles cited in this study and the year when the articles were published. The study identified several definitions of the service encounter and also found that there are several dimensions and types of the service encounter. The divergent views that emanate from these findings stem from the fact that there is a growth in literature and the body of knowledge on the service encounter in different sectors of the economy. The findings of this study could assist academics and practitioners to have a deeper understanding of the service encounter. Such an understanding is very critical in addressing the needs of students and other stakeholders of higher education institutions. Moreover, it can help faculty members and institutional managers deal with moments of truths which if properly managed can facilitate the realisation of student expectations and ultimately, satisfaction. This study further provides a basis for future research using the available service encounter evaluation tools or instruments.
\end{abstract}

Key words: service encounter, moment of truth, higher education institutions, service evaluation, customer satisfaction, service quality.

JEL Classification: 123, L80, L84, M31

\section{Introduction}

Although most customers expect extraordinary service experiences, in reality, they rarely occur. In selected cases when customers get an extraordinary experience, they are normally in disbelief that a service provider would deliver a quality service that deviates from an expected service norm (Collier, Barnes, Abney \& Pelletier, 2018). The process of consumption for most goods and services involves an exchange process between the customer and the organisation. These exchanges or SEs (also known as "moments of truth") act as a yardstick for service quality evaluation. Conversely, these exchanges provide the organisation with several opportunities

\footnotetext{
Corresponding author:

${ }^{1}$ Mangosuthu University of Technology, South Africa.

Email: kayambazinthu@outlook.com

ORCID: https://orcid.org/0000-0001-9074-5644

ResearcherID: E-5654-2019

Scopus Author ID: 57003422600
}

to evaluate the perception of customers regarding the quality of the service received or delivered. Thus, one of the ways of improving service quality is for service providers to understand the whole SE experience (John, 1996). The service sector is known for the moment of truth or the SE, many of which leave marks of unpleasant and negative feelings while others leave marks of positive feelings (Weeks, 2015). In most cases, the SE takes place in full view of other students. The nature of the service received by one student helps other students to form their own expectations of an ideal service (Anaya, Miao, Mattila \& Almanza, 2016). Every SE is unique such that an element of 
student impressions and satisfaction with the higher education institution is cumulative. Thus, the spillover of the outcomes from previous SEs underlines the value of the overall SE experience. The touchpoints such as the classroom, online student portals, posters, and brochures are the higher education institution's mechanism to facilitate the SE and interactions with students (Voorhees, Fombelle, Gregoire, Bone, Gustafsson, Sousa \& Walkowiak, 2017).

The higher education sector, specifically universities world over is at a crossroads as a result of the increase in the number of unresolved complaints. Students complain about the lack of a functional system to apprise them regarding the status of their complaints (Bothwell, 2016). The treatment of students as customers has been a subject of debate. The customer narrative has several advantages that it presents to the students. Extant research suggests that students should be legitimately treated as customers of the university because they have the same rights as other customers. These rights include the right to register a complaint regarding poor teaching methods, university facilities, outdated books in the library, cumbersome processes and poor accommodation (Hussey \& Smith, 2010). With this perspective in mind, it must be noted that students as customers, interact with members of the faculty, and other departments, such as finance, housing, and the library through a process known as the SE. The SE facilitates the exchange process between an organisation and the customer. Thus, the benefits received by a party to a transaction during the process of exchanges are contingent on the benefits that the other party receives. For instance, when resolving customer complaints, the firm will only address the complaint if the customer will continue with the relationship as a result of the complaint being resolved. Simply put, both parties exchange value if the mutual benefits derived from the transaction are adequate (Boshoff, 2017).

The SE is very important for service providers and is also an opportunity for higher education institutions to exceed the expectation of students. However, employees' negative attitude, coupled with poor service performance, gives students a bad impression of the service provider and they tend to believe that the service experience has been unreasonable. Such negative attitudes include ignoring students and interacting impersonally (Fukawa \& Erevelles, 2014). Therefore, the ability of institutional employees to read students behaviour expressed emotions and facial expressions will enable them to read students' silent feedback. This will enable the institution's employees to correct service failures in real-time even in the absence of the student explaining his or her dissatisfaction with the SE (Mattila \& Enz, 2002).

Ultimately, students expect value for their money. Thus, higher education institutions have a challenge or an obligation to improve their services, facilities and also to be pro-active in responding to students' complaints. Failure to meet students' needs and expectations may lead to dissatisfaction and, subsequently, the service will be deemed to have failed (Fosu \& Owusu, 2015). The higher education environment is volatile and susceptible to change in the blink of an eye such that the onus is on the service provider to deliver a SE experience of high quality to win the allegiance of timepressed students. The understanding of SEs is crucial for institutions to be able to re-engineer business and service processes. The absence of effective tools to monitor and capture students' behaviour throughout the service lifespan is a major setback to institutions in their quest to gaining insight or information about SEs. The advent of technology has provided a platform for institutions to start tracking SEs' performance. Therefore, institutions must embrace technology in their operations so that social and transactional interactions can be monitored (Qiu, 2013).

Previous research avers that the SE that is definitive and heart-felt is outstanding than a "hi and bye" interaction, especially as the basis for a sustainable relationship. Thus, relationships should be created naturally by service employees who are driven by a meaningful purpose and are passionate about the work they do. In service systems where human interventions are key, students feel valued to be assisted by such employees (Bolton, Gustafsson, McColl-Kennedy, Sirianni \& Tse, 2014). The behaviour of lecturers is critical for effective interaction and service delivery during the SE. They are the ambassadors of the institution. As such, their appearance, demeanour, body language, facial expression, language, and tone have a great influence on the student service experience and evaluation. Even with the best lecturers, the SE can be unpleasant if etiquette is not valued and followed (Cockerell, 2013).

One of the most important aspects of higher education is student engagement in their studies and university life in general which is crucial to attracting students and maximising their success. Universities need to position themselves as offering quality and different services that meet student expectations (O'Connor \& Moodie, 2007). However, the challenge is that some higher education institutions tend to oversell their potential and academic readiness by boasting that they have state-of-the-art learning facilities, technology, laboratories and other supporting infrastructure. Therefore, this rhetoric and misrepresentation of their actual capacity help students to build fuzzy expectations. Another observation is that sometimes students receive a service that is hugely compromised because university lecturers assume multiple roles such as stand-up lecturing, curriculum development, mentoring, project supervision, and other administrative responsibilities. As such, the level of service quality delivered may become less desirable and standardised (Yeo, 2008). 
Service failure during encounters is unavoidable despite efforts to offer a zero defects service. Employees may be rude to students, lecturers may not show up for the scheduled class, the classroom environment may be dirty and congested. Students experience an unpleasant SE because the service has not been delivered as expected or planned (Ennew \& Schoefer, 2003). Similarly, when faculty members exhibit inappropriate behaviour and attitude towards students, their reaction may be negative because, naturally, students expect the behaviour of faculty members to be above the board. Also, the personal opinions and biases of faculty members may have a negative impact on the learning experience and, consequently, students may be helpless in dealing with the situation (Hoffman \& Lee, 2015). Lloyd and Luk (2011) have noted that while it is important to get a good outcome during the SE, employees of higher education institutions such as lecturers need to pay attention to small things like gestures and other behaviour cues. Thus, students form perceptions regarding the SE not only from the outcome of the service but also from the interaction (process) such that it is important to emphasize to the institutional employees the need to ensure quality during the interaction as that forms the basis for assessing service quality and the SE. This study performed a systematic literature review of the SE using sources from 1984 to 2018. Specifically, the meaning of the SE, the dimensions, the types of the SE and the methods of evaluation.

\section{Methodology and design}

This paper adopted a non-empirical approach to collect information from different sources. An extensive search and review of the literature were conducted from different journal articles, books, conference proceedings and websites. A plethora of studies on the SE were reviewed from a total of 73 sources but only 50 sources were cited in this study. From the information collected, and reviewed, various SE models have been discussed to ground the discussion and lay a solid foundation of the concept. Furthermore, a lecturer- student SE framework has been developed to provide a picture and an understanding of a basic classroom SE evaluation experience in institutions of higher learning. Simply put, this study sought to provide a theoretical perspective of the SE in higher education institutions and how it is evaluated.

\subsection{Research questions}

A systematic literature review was conducted to addressing the following issues: (1) the definition of the service encounter; (2) the dimensions of the service encounter; (3) the types of service encounter; (4) methods of evaluating service encounter in higher education institutions. Therefore, Table 1 illustrates the research questions underpinning this study.
Table 1

Research questions underpinning this study

\begin{tabular}{|c|l|}
\hline ID & \multicolumn{1}{|c|}{ Research Questions } \\
\hline RQ1 & What is the service encounter \\
\hline RQ2 & What are the dimensions of the service encounter \\
\hline RQ3 & What are the types of service encounter \\
\hline RQ4 & $\begin{array}{l}\text { What are the methods used to evaluate the service } \\
\text { encounter in higher education institutions }\end{array}$ \\
\hline
\end{tabular}

\section{Results and discussion}

\subsection{Data sources}

In terms of the classification of the sources cited in this study, out of 50 articles, 40 articles cited were journals articles representing $80 \%$ percentage of the sources followed by 7 books representing 14\%, 2 articles were cited from the internet representing $4 \%$ and 1 article from conference proceedings representing $2 \%$ of the sources cited as shown in Figure 1. Figure 1 shows the number of articles cited per source (journals, books, internet and conference proceedings).

The information used in this study was also grouped or categorised based on the year of publication as illustrated in Figure 2. Thus, 5 articles were published in 2017 followed by 4 articles published in 2015 and 2012, 3 articles published in 2014, 2013, 2008 and 2006, 2 articles per the year of publication (2018, 2016, 2011, 2005, 2003, 2000, 1996) respectively were used in this study. Only 1 article per the year of publication $(2010,2007,2002,1999,1994,1992$, $1990,1987,1985$ and 1984) was cited in this study as shown in Figure 2. The results further show that there is an increase in the scientific interest on the SE in the latter years since the majority of sources used were from recent publications. Figure 2 shows the number of articles published each year (from 1984 to 2018) that were cited in this study.

\subsection{What is the service encounter}

Every component of the service process where students engage with higher education institutions presents an opportunity for a service breakdown. While the importance of processes may be undermined, others may be critical for a good student experience (Palmer, 2011). Thus, the SE is the meeting and interaction between a service provider such as a faculty manager, a lecturer and a student. It is sometimes known as the "moment of truth" Solomon, Marshal \& Stuart, 2012). Table 2 shows the results of previous studies on the conceptualisation of the SE based on different schools of thoughts by eminent scholars.

\subsection{What are the dimensions of the service encounter}

A plethora of studies on the SE have come up with different dimensions. For instance, previous research 
Vol. 7 No. 3, 2021

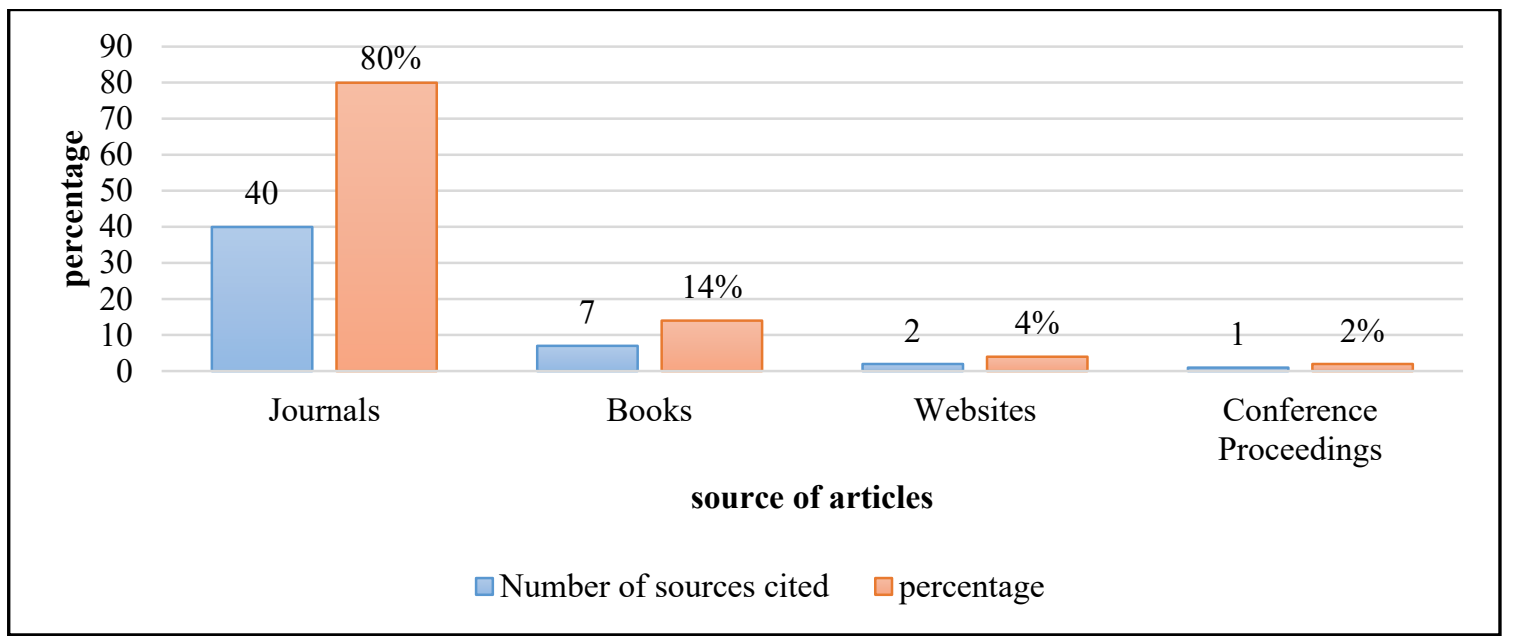

Figure 1. Number of articles cited per source

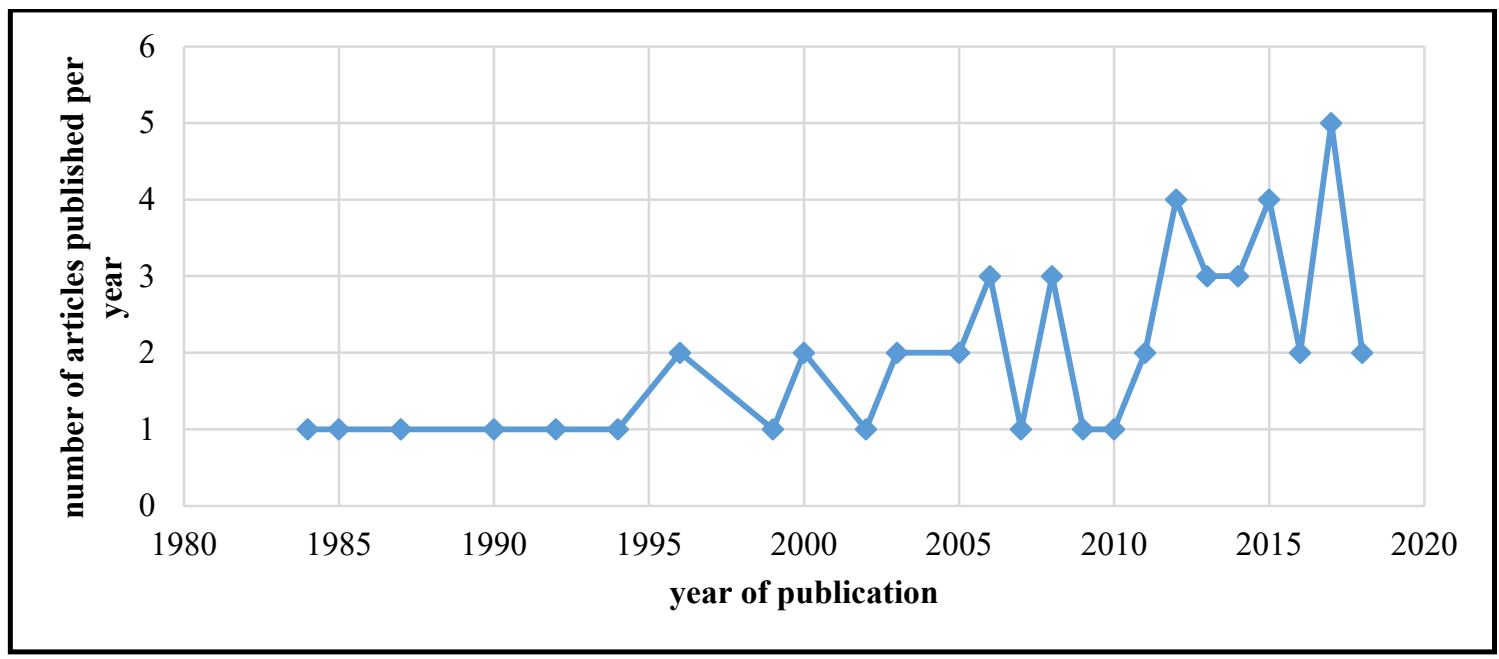

Figure 2. Number of articles published per year

suggests that the three dimensions of the SE are pre-core $\mathrm{SE}$, the core SE, and the post-core SE. The pre-core SE period is the time interval before the core SE that focuses on leading students to interact with the institution in the core-SE. Thus, this period includes numerous SEs. The pre-core SE takes place when students start searching and evaluating information about the institution's service offering or make enquiries with the institution. Some of the scenarios of pre-core SEs are seeking information from online reviews, asking questions to front desk employees and onboarding processes. The examples during this stage encompass activities like orientation for first-year students on services available on campus (Voorhees et al, 2017).

The core SE period refers to the period during which the primary service offering is given to the student. The primary service is aimed at meeting the student's basic needs which is instrumental in motivating the student to engage with the institution. This period is known as the moment in which the student is "in the factory" and the core interactions are between students and institutional employees such as lecturers and librarians, other students and technologies. This stage encompasses activities such as the delivery of a lecture (Bitner, Brown \& Meuter, 2000). The postcore SE refers to the period that follows the core SE. During this period, students analyse and act based on prior experience emanating from the two previous periods. In this period, the institution's goal is to retain most of the students and foster an improvement to subsequent SEs. Post-core encounters encompass activities such as the receipt of a student survey, social media posts request, scenarios involving a student complaint, or the institution's initiatives to maintain a good relationship with students (Voorhees et al., 2017). According to Walker (1995), the SE evaluation is a function of three distinct integrated stages, i.e. peripheral service performance, core service 
Table 2

Results of the Studies on the conceptualisation of the service encounter

\begin{tabular}{|c|c|c|}
\hline Authors & Domain & Definition \\
\hline $\begin{array}{l}\text { Surprenant and } \\
\text { Solomon (1987:87) }\end{array}$ & Service encounter & "Dyadic interaction between a customer and a service provider." \\
\hline $\begin{array}{l}\text { Larivière et al. } \\
(2017: 239)\end{array}$ & Service encounter & $\begin{array}{l}\text { "any customer-company interaction that results from a service system that is comprised } \\
\text { of interrelated technologies (either company- or customer-owned), human actors } \\
\text { (employees and customers), physical/digital environments and company/customer processes." }\end{array}$ \\
\hline Shostack (1985:243) & Service encounter & "a period of time during which a customer directly interacts with a service." \\
\hline $\begin{array}{l}\text { Drennan } \\
\text { and McColl-Kennedy } \\
(2003: 296)\end{array}$ & Service encounter & "traditionally, SEs have been characterized as low tech, high face-to-face contact." \\
\hline John $(1996: 61)$ & Service encounter & $\begin{array}{l}\text { "is a personal (and social) interaction between a service provider and service customer. } \\
\text { A service encounter is a social encounter, especially in high contact service experiences. } \\
\text { As social interactions, all service encounters are performed within the context of the cultural } \\
\text { background of the participants: that is, both the client and the service provider representing } \\
\text { the organization." }\end{array}$ \\
\hline $\begin{array}{l}\text { Patterson and Mattila } \\
(2008: 262)\end{array}$ & Service encounter & $\begin{array}{l}\text { "are first and foremost social exchanges, with the interaction between a service provider } \\
\text { and customer being a crucial component of satisfaction and providing a motive to continue } \\
\text { relationships." }\end{array}$ \\
\hline $\begin{array}{l}\text { Voorhees et al. } \\
(2017: 270)\end{array}$ & Service encounter & $\begin{array}{l}\text { "any discrete interaction between the customer and the service provider relevant to a core } \\
\text { service offering, including the interaction involving the provision of the core service offering } \\
\text { itself." }\end{array}$ \\
\hline Norman (1984) & Service encounter & $\begin{array}{l}\text { "Any episode in which the customer comes into contact with any aspect of the organization } \\
\text { and gets an impression of the quality of its service." }\end{array}$ \\
\hline Qiu $(2013: 1)$ & Service encounter & $\begin{array}{l}\text { "Service encounters involve all interacting activities in the service delivery process, creating } \\
\text { a reciprocal influence between service providers and customers. For example, consumers are } \\
\text { the customers in the retailing service sector, students are the customers in educational service } \\
\text { systems, and patients are the customers in healthcare delivery systems. Surely, it is the service } \\
\text { encounter that enables the necessary manifest function that engages the providers } \\
\text { and customers in order to show the "truth" of service." }\end{array}$ \\
\hline
\end{tabular}

performance, and overall SE. The model explains what happens in a typical SE scenario. It further highlights that student expectations can change during the SE. Before consumption of the core service, consumers encounter peripheral components which may include employee personality and attitude and subsequently compare the performance with the expectations which are regarded as passive. The impression created by the service provider sets the direction or tone for future interactions. The overall SE is a function of the three integrated stages and determines whether the customer is satisfied, dissatisfied or neutral. For instance, in a higher education institution and specifically teaching, attention will be drawn to the environment in which the lecture will be delivered, the reputation of the institution, the clothes or grooming of the lecturer and not the core service of learning. Ramdas, Teisberg and Tucker (2012) suggest there are four dimensions of the SE viz. the structure of the interactions, the service boundary, the allocation of service tasks, and the delivery location. The authors argue that service providers such as higher education institutions should define and deliver services by evaluating interactions using the four dimensions as one way of creating mutual values for both parties to a transaction, i.e. higher education institutions and students. In the same vein, Qiu (2013) argue that in the fast pacing digital and global economy where change is the only constant, conventional wisdom may not always be true. Thus, to generate knowledge that can be applied scientifically in a dynamic environment, there is a need for service science to help in fostering the engineering, planning, design, delivery, and operations of person-centred integrative SEs.

Extant research suggests that the SE is crucial to the student's service experience. The quality of the service experience during the SE has a bearing on students' satisfaction and their perception of the institution and its employees. The SE is a multidimensional concept and includes the social contact dimension (SED) and the physical dimension (PD). The SED is the interaction between the faculty member and the student. The PD entails that students value the environment used to provide or deliver the service. Service providers can minimise dissatisfying SEs or experiences through disintermediation. Disintermediation is an internal procedure where human interference is eliminated when discharging a service and is replaced with technology or equipment (Solomon, Marshal \& Stuart, 2012). For example, higher education institutions can 
adopt the use of technology and conduct processes such as online registration. Another school of thought suggests that the SE has three dimensions, i.e. temporal duration, affective or emotional content and the spatial proximity of the service employee and student. The three dimensions play a significant role in relationship development and the outcome of the SE. This means that any variation in the three dimensions of the SE will have a significant impact on the service providers' performance and outcome. It further shows that service providers' performance has a direct impact on affective responses and satisfaction and an indirect impact on satisfaction through affective response. Service providers' performance during an interaction can either lead to positive or negative reactions (Price, Arnould \& Tierney, 1995). Therefore, service failure will occur if the reaction is negative or the student is not satisfied with the encounter. Mattila and Enz (2002) claim that the affective response has a significant impact on student encounter-level evaluation even in the context of short and monotonous SEs.

\subsection{What are the types of the service encounter}

The SE can be categorised as a remote encounter, a telephone encounter or a face-to-face encounter. A student can experience any of the three or a combination of the three. Remote encounters are SEs that occur without human interaction or contact such as registration through a web-based portal. Even in the absence of human contact, the SE is an opportunity for the service provider to reinforce student perception of the quality of the service sought. In some organisations, SEs are done or experienced through a telephone conversation. However, the chances of variability in the interaction are high in a telephone conversation. The tone, knowledge of employees and efficiency in handling student issues or queries form an important criterion for assessing service quality on the part of the student. In face-to-face SEs, both verbal and non-verbal cues are important for ascertaining service quality (Wilson, Zeithaml, Bitner \& Gremler, 2012).

The SE can also be viewed in terms of the level of contact. Some SEs are short or brief, whereas others are long. High contact services are those where there is direct contact between the student and the service provider. During high contact SEs, students are exposed to physical cues about the service provider. These cues may include the appearance and behaviour of employees. In low contact SEs, there is little and, in some cases, no contact between the student and service provider. Contact is done through equipment or physical distribution channels. Recently, most of the services are migrating from high to low contact because, in the modern era, high contact services are regarded as a recipe for inconvenience (Wirtz, Chew \& Lovelock 2018).

\subsection{What are the methods of evaluating the service encounter}

There are several attributes used to evaluate service encounter quality. For instance, Douglas, Douglas, McClelland, and Davies (2015) suggest that the key determinant of quality is access, attentiveness, availability and communication. Access encompasses service location, ease of the environment and contact with university staff. Attentiveness encompasses staff willingness to help or assist a student by providing the necessary support. Availability refers to staff dedication in terms of the time they can give and listen to students, whereas communication is the ability of the university to engage with students using the medium or language they understand. It encompasses things such as lecturers' communication when classes are cancelled, providing feedback on modules and supervision of students. Students have some expectations which, at a minimum, mus $t$ be met by the institution. However, when faculty members are late for classes, do not interact with students, have ambiguous or unfair policies, the overall classroom experience becomes distracted. Consequently, the faculty must set standards that must be adhered to by its members (Hoffman \& Lee, 2015).

Students as customers of the university approach the SE with different forms of expectation, ranging from unfamiliar situations that are not well defined to well-defined familiar ones. What is critical for service providers to know is that whether expectations are met or not will have an impact on the perceived quality of service. The majority of SEs require close interaction between a service provider and the consumer. To determine whether the interaction was satisfactory or not depends on several factors such as the appearance of the faculty member and his or her perceived level of competence. Although the factors raised may contribute to service heterogeneity and variability, they are difficult to control (Rasli, Danjuma, Yew \& Igbal, 2011). Boshoff (2017) believes that regardless of the facial features of service employees, their appearance should not be overlooked. The university employees, such as lecturers physical appearance must reflect respect for themselves and their students. Thus, there is a need for proper grooming and a professional dress code that portrays them as 'professional' rather than 'sexy'. Service quality is largely dependent on the perception of students based on their SE experience. When student expectations are high, the level of tolerance for service failure is low. However, universities can modify student expectations by offering different choices to them. What is critical to offset any negative perception regarding the service being offered is that the support services and facilities should play a very important role in contributing to overall service quality in higher education and not only focus on academic excellence alone (Yeo \& Li, 2014). 
Table 3

Evaluation methods of the service encounter

\begin{tabular}{|l|c|c|}
\hline \multicolumn{1}{|c|}{ Authors } & Domain & Methods of evaluation \\
\hline $\begin{array}{l}\text { Tan (2012); Cronin and Taylor (1992); } \\
\text { Alexiadou et al., (2017) }\end{array}$ & SE in the service sector & SERVPERF \\
\hline $\begin{array}{l}\text { Parasuraman et al., (1991; 1988), } \\
\text { Durvasula et al., (2005) }\end{array}$ & SE in the service sector & SERVQUAL \\
\hline Bitner et al., (1990) & SE in the service sector & CIT \\
\hline Firdaus (2005; 2006) & SE in the service sector & HEdPERF \\
\hline Smith et al., (1999) & SE in the service sector & Experimental design and 12 items scale questionnaire \\
\hline Yazdanpanah et al., (2013) & SE in the service sector & 21 items scale questionnaire \\
\hline Migdadi, (2008) & SE in the service sector & Website QEM \\
\hline Azza and Norchene (2017) & SE in the service sector & 27 items scale questionnaire \\
\hline
\end{tabular}

According to Brochado (2009), the evaluation of the $S E$ requires one to determine service quality such that the instruments used to evaluate the SE are similar to the ones used to measure service quality. Thus, SEs that are properly managed enhance customers' perception of service quality. According to Bitner (1994), evidence of service quality occurs during the service encounter. Previous research on the SE has been conducted in different sectors of the economy using various research instruments and methods of evaluation. For instance, Tan (2012) and Alexiadou evaluated SEs using the SERVPERF instrument developed by Cronin and Taylor (1992). Similar studies have also been conducted by Durvasula et al., (2005) using the SERVQUAL which was developed by Parasuraman (1991, 1988). Bitner et al, (1990) evaluated service encounters using the Critical Incident Technique (CIT). This is one of the groundbreaking studies on the SE which relies on the recall of memorable SE events or scenarios. Another instrument that has specifically been used to evaluate service encounter quality in the higher education sector is the HERdPERF (Fridaus, 2005; 2006). Also, Smith et al., (1999) evaluated service encounters using an experimental design and 12 items scale questionnaire. Other studies that evaluated the service encounter used 21 items scale questionnaire (Yazdanpanah et al., 2013), the website QEM (Migdadi, 2008) and a 27 items scale questionnaire (Azza \& Norchene, 2017). Table 3 shows the SE methods of evaluation and these are related to research question number 4 .

\section{Conclusion}

In this paper, the SE has been discussed from the conceptualization to how it is evaluated. The SE is the heart of the service delivery process in the higher education sector. It is an integral part of the process that ensures that the final product is delivered to the satisfaction of the student. However, it must be noted that the SE depends on the conduct or performance of university employees, lecturers and tools (machines and computers) that aid service delivery. Thus, the failure of either an employee or the service touchpoints to perform optimally is deemed as the failure of the whole process aimed at assisting the student to meet his or her needs. Simply put, that is the moment of truth. This study sought to provide information on the SE, specifically the higher education sector because most of the previous studies have been conducted in a profit-making business environment. Therefore, this study facilitates the understanding of students as customers of the university. The reviewed literature has provided several definitions of the SE that are key to its conceptualization. Besides, the literature shows evidence of various dimensions and types of the SE. The findings have further unearthed the different methods of evaluating the SE. Ultimately, the evaluation of the encounter is not independent of each part of the process. Students look at the totality of the SE to ascertain whether the SE was satisfactory or not. This study contributes to the literature and an understanding of the SE in the higher education sector. From the academician and practitioner point of view, the evaluation of the SE is vital because it can serve as a benchmark of the institution performance in relation to other services provided by other institutions. Furthermore, the SE evaluation enables an institution to evaluate the current level of service quality thereby providing a launchpad for quality improvements. Future research should focus on empirical findings on the SE in the higher education sector.

\section{References:}

Alexiadou, C., Stylos, N., Andronikidis, A., Bellou, V., \& Vassiliadis, C. A. (2017). Quality in bank service encounters: Assessing the equivalence of customers' and front-line employees' perceptions. International Journal of Quality \& Reliability Management, 34(9), 1431-1450. DOI: https://doi.org/10.1108/IJQRM-04-2016-0049

Anaya, G. J., Miao, L., Mattila, A. S., \& Almanza, B. (2016). Consumer envy during service encounters. Journal of Service Marketing, 30(3), 359-372. 
Azza, T. B., \& Norchene, B. D. (2017). Social and physical aspects of the service encounter: Effects on trust and customer loyalty to the service provider. Advances in Economics and Business, 5(1), 1-10.

Bitner, M. J., Brown, S. W., \& Meuter, M. L. (2000). Technology infusion in service encounters. Journal of the Academy of Marketing Science, 28(1), 138-149.

Bitner, M. J., Booms, B. H., \& Mohr, L. A. (1994). Critical Service Encounters: The Employees. Viewpoint. Journal of Marketing, 58, 95-106.

Bitner, M. J., Booms, N. H., \& Tetreault, M. S. (1990). The Service Encounter: Diagnosing Favorable and Unfavorable Incidents. Journal of Marketing, 54, 71-84.

Bolton, R., Gustafsson, A., McColl-Kennedy, J. J., Sirianni, N. \& Tse, D. (2014). Small details that make big differences: a radical approach to consumption experience as a firm's differentiating strategy. Journal of Service Management, 25(2), 253-274.

Boshoff, C. (2017). An assessment of consumers' subconscious responses to frontline employees' attractiveness in a service failure and recovery situation. South African Journal of Economic and Management Sciences, 20(1), 1-13.

Bothwell, E. (2016). Universities with most unresolved student complaints revealed. Available at: https://www.timeshighereducation.com/news/universitiesmostunresolved-student-complaints-revealed (accessed 23 April 2021).

Brochado, A. (2009). Comparing alternative instruments to measure service quality in higher education. Quality Assurance in education, 17 (2), 174-190. DOI: https://doi.org/10.1108/09684880910951381

Collier, J. E., Barnes, D. C., Abney, A. K. \& Pelletier, M.J. (2018). Idiosyncratic service experiences: When customers desire the extraordinary in a service encounter. Journal of Business Research, 84, 150-161.

Cockerell, L. (2013). The customer rules. Leader to Leader, 2013(69), 7-11.

Cook, C. \& Bruce, T. (2000). Reliability and Validity of SERVQUAL Scores Used to Evaluate Perceptions of Library Service Quality. The Journal of Academic Librarianship, 26(4), 248-258.

Cronin, J. J. Jr., \& Taylor, S. A. (1992). Measuring Service Quality: A Reexamination and Extension. Journal of Marketing, 56, 55-68.

Douglas, J. A., Douglas, A., McClelland, R. J., \& Davies, J. (2015). Understanding student satisfaction and dissatisfaction: an interpretive study in the UK higher education context. Studies in Higher Education, 40(2), 329-349.

Durvasula, S., Lysonski, S., \& Mehta, S.C., (2005). Service encounters: the missing link between service quality perceptions and satisfaction. Journal of Applied Business Research (JABR), 21(3).

Drennan, J., \& McColl-Kennedy, J. R. (2003). The Relationship between Internet Use and Perceived Performance in Retail and Professional Service Firms. Journal of Services Marketing, 17 (2/3), 295-312.

Ennew, C., \& Schoefer, K. (2003). Service failure and service recovery in tourism: A review. Christel DeHaan Tourism and Travel Research Institute, Nottingham University Business School.

Fukawa, N., \& Erevelles, S. (2014). Perceived reasonableness and morals in service encounters. Journal of Business Ethics, 125(3), 381-400.

Fosu, F. P., \& Owusu, B. K. (2015). Understanding Ghanaian students' perception of service quality in higher education. European Journal of Business and Management, 7(9), 96-105.

Firdaus, A. (2005). The Development of HEdPERF: A New Measuring Instrument of Service Quality for the Higher Education Sector. International Journal of Consumer Studies, 30(6), 569-581.

Firdaus, A. (2006). Measuring Service Quality in Higher Education: HEdPERF versus SERVPERF. Marketing Intelligence \& Planning, 24(1), 31-47.

Hoffman, K. D., \& Lee, S. H. (2015). A CIT investigation of disruptive student behaviours: the students' perspective. Marketing Education Review, 25(2), 115-126.

Hussey, T., \& Smith, P. (2010). The trouble with higher education: a critical examination of our universities. New York, NY: Routledge.

John, J. (1996). A dramaturgical view of the health care service encounter: Cultural value-based impression management guidelines for medical professional behaviour. European Journal of Marketing, 30 (9), 60-74. DOI: https://doi.org/10.1108/03090569610130043

Larivière, B., Bowen, D., Andreassen, T.W., Kunz, W., Sirianni, N.J., Voss, C., Wünderlich, N. V., \& De Keyser, A. (2017). "Service Encounter 2.0": An investigation into the roles of technology, employees and customers. Journal of Business Research, 79, 238-246.

Lloyd, A. E., \& Luk, S. T. K. (2011). Interaction behaviours leading to comfort in the service encounter. Journal of Services Marketing, 25(3), 176-189.

Mattila, A. S., \& Enz, C. A. (2002). The role of emotions in service encounters. Cornell University School of Hotel Administration. Available at: http://scholarship.sha.cornell.edu/articles/618. Accessed 2 February 2019

Migdadi, Y. K. (2008). Quantitative Evaluation of the Internet Banking Service Encounter's Quality: Comparative Study between Jordan and the UK Retail Banks. The Journal of Internet Banking and Commerce, 13(2), 1-8.

Normann, R. (1984). Service Management. Chichester: John Wiley \& Sons. 
O’Connor, I., \& Moodie, G. (2007). Major issues facing universities. In: Universities Australia Staff Development and Training Program Student Administration Conference, Brisbane.

Palmer, A. (2011). Principles of services marketing. 6th ed. Berkshire: McGraw-Hill.

Patterson, P. G., \& Mattila, A. S. (2008). An examination of the impact of cultural orientation and familiarity in service encounter evaluations. International Journal of Service Industry Management, 19(5), 662-681. DOI: https://doi.org/10.1108/09564230810903514

Price, L. L., Arnould, E. J., \& Tierney, P. (1995). Going to extremes: Managing service encounters and assessing providers' performance. Journal of Marketing, 59, 83-97.

Qiu, R. G. (2013). We must rethink service encounters. Service Science, 5(1), 1-13.

Ramdas, K., Teisberg, E., \& Tucker, A. L. (2012) Four ways to reinvent service delivery. Harvard Bus. Rev, 90(12), 98-106.

Rasli, A., Danjuma, I., Yew, L. K., \& Igbal, M. J. (2011). Service quality, customer satisfaction in technology-based universities. African Journal of Business Management, 5(15), 6541.

Shostack, G. L. (1985). Planning the Service Encounter. In J. A. Czepiel, M. R. Soloman, \& C. F. Suprenant (Eds.), The Service Encounter (pp. 243-254). Lexicon, MA: Lexicon Books.

Smith, A. K., Bolton, R. N. \& Wagner, J. (1999). A model of customer satisfaction with service encounters involving failure and recovery. Journal of marketing research, 36(3), 356-372.

Solomon, M. R., Marshall, G. W., \& Stuart, E. W. (2012). Marketing: Real people real choices. 7thed. Boston Ma: Pearson.

Suprenant, C. F., \& Solomon, M. R. (1987). Predictability and personalization in the service encounter. Journal of Marketing, 51(2), 86-96.

Tan, T. A. G., (2012). Evaluating Service Encounters: The Effects of Employee Responses on Service Failure and Recovery. IAMURE International Journal of Education, 2(1), 1-1.

Voorhees, C. M., Fombelle, P. W., Gregoire, Y., Bone, S., Gustafsson, A., Sousa, R., \& Walkowiak, T. (2017). Service encounters, experiences and the customer journey: Defining the field and a call to expand our lens. Journal of Business Research, 79, 269-280.

Walker, J. L. (1995). Service encounter satisfaction: Conceptualised. The Journal of Services Marketing, 9(1).

Weeks, R. V. (2015). Managing the service encounter: The moment of truth. Journal of Contemporary Management, $12,360-378$.

Wilson, A., Zeithaml, V. A., Bitner, M. J., \& Gremler, D. D. (2012). Services marketing: Integrating customer focus across the firm. Berkshire: McGraw Hill.

Wirtz, V., Chew, P., \& Lovelock, C. (2018). Essentials of services marketing. 3nded. Essex: Pearson.

Yazdanpanah, Y., Feizi, M., \& Abad, M. H. M. (2013). Relative importance of Service Encounter Quality Dimensions and Customer Satisfactionin Meshkin City's Mellat Banks. Nigerian Chapter of Arabian Journal of Business and Management Review, 62(1092), 1-8.

Yeo, R. K. (2008). Brewing service quality in higher education: characteristics of ingredients that make up the recipe. Quality Assurance in Education, 16(3), 266-286.

Yeo, R. K., \& Li, J. (2014). Beyond SERVQUAL: the competing forces of higher education in Singapore. Total Quality Management, 25, 95-123. 